\title{
SOUTH KOREA'S OUTWARD FOREIGN DIRECT INVESTMENTS IN SOUTHEAST ASIA: TRENDS, MOTIVATION AND CASE STUDIES
}

\author{
Soo Kee Tan
}

\section{Introduction}

A growing number of firms are starting to identify foreign direct investment as an important international corporate strategy. FDI enables firms not only to expand their market, but also to benefit from lower cost and new technologies, depending on the purpose of investment. To explain the activities of foreign direct investment, Hymer demonstrated that 'market imperfection in the world (e.g. due to trade barrier, information cost etc) makes firms to globalize their production activities. ${ }^{1}$ Dunning stated that firms will invest overseas when there are ownership advantage, location advantage of the investment destination, and internalization advantage for firms to set up their own operations rather than licensing, export or subcontracting. ${ }^{2}$ Imbalance Theory of Moon suggests that firms also invest overseas to seek new advantages, such as technology and skills to compensate for their disadvantage in their home country. ${ }^{3}$ Due to the substantial benefits of investing overseas, outward foreign direct investments firms from developing countries have grown significantly in the past few decades. One of the best examples is South Korea. In Korea, foreign investment is an approach used by big business firms to expand their markets to compensate for limited sales in their own country, and to leverage on production efficiencies. In fact, South Korea has become one of the largest investor nations in the Asian region after Japan.

Although the Korean outward FDI began in the 1960s, the overseas direct investment activities only started to be active in the early 1990s. The rise in local production cost, limited home market, lack of natural resources and the growth of business for Korean firms were the key drivers of Korean outward FDI. In terms of investment locations, Southeast Asia ranked first for Korean FDI's destination in the 1990s, followed by the U.S and Europe. ${ }^{4}$ In the early stage, the focus of Korean Outward FDI was on resource seeking, to offset higher domestic production costs as a result of appreciation of Korean

1 S.H., Hymer,"The international Operation of National Firms: A study of Direct Foreign Investment", Cambridge, MA, MIT Press, 1976.

2 J.H., Dunning," International Production and the Multinational Enterprise", London, George Allen and Unwin, 1988.

3 H. C., Moon, "The Evolution of Theories of Foreign Direct Investment", Review of Business History, Vol 19, No 1, 2004.

4 K.H., Park, "External Factors Inducing Korean Overseas Direct Investment", The Journal of the Korean Economy, Vol. 1, No. 1, Spring 2000), pp 191-205. 
Won. ${ }^{5}$ The abundance of natural resources, cheap labor and large market in Southeast Asian countries (particularly Indonesia) have attracted Korean firms to invest in the region. Limited domestic applicability has pushed Korean MNCs to seek investment opportunities in developing countries.

To examine the key drivers of Korean MNCs investments in overseas countries, this paper focuses on the study of the region of Southeast Asia. There are four types of motivation of FDI namely market seeking, resource seeking, efficiency seeking and created asset seeking. The type of investments of Korean MNCs in Southeast Asia is downward investment, which mainly aims for cheaper resources; thus, this study excludes the study on created asset seeking. This paper will discuss the FDI theories, followed by current status and trend of Korea's FDI in Southeast Asia and the motivation of Korean FDI, all of which are supported by case studies of Korean MNCs investments. Finally, the conclusion of this study will summarize all the findings.

\section{Motivation of Foreign Direct Investment}

Based on the FDI theories, multinational corporations (MNCs) prefer FDI when they find that the external markets are inefficient. ${ }^{6}$ Dunning's Internationalization theory suggests that if the external markets of exporting and licensing are costly, MNCs will internalize the transactions within their organizations. The Internationalization theory was later extended by Dunning with two additional variables, namely ownership advantage and location. ${ }^{7}$ The model is called OLI paradigm, which suggests that a firm will opt for overseas investment when it has either organizational advantage (trademark, production technique, entrepreneurial skills), or the targeted investment destination has location advantage (availability of raw materials, low wages, special taxes or tariffs). Instead of indirectly benefiting from its advantages by producing through partnership arrangements such as licensing or joint venture, the firm is inclined to internalize these advantages by producing in a foreign country. ${ }^{8}$ Currently, John Dunning's ILO model is the dominant FDI theory.

Dunning also classifies FDI as market seeking, efficiency seeking, resource seeking and created-asset seeking. A firm elects to invest overseas for many purposes. These include seeking new customers (market-seeking FDI); cutting costs (efficiency-seeking FDI); accessing crucial inputs (resources-seeking FDI, perhaps in a country rich in raw materials); or acquiring new technologies to enhance productivity (created asset-seeking FDI, perhaps in developed economies), or a combination of these purposes ${ }^{9}$

5 Ibid.,

6 H. C., Moon, "The Evolution of Theories of Foreign Direct Investment", Review of Business History, Vol.19, No 1, 2004.

7 J.H. , Dunning, " The Eclectic Paradigm Of International Production: A Restatement And Some Possible Extensions", Journal of International Business Studies, Vol. 19, No.1, pp 1-32, 1988.

8 M.J., Twomey, "A Century Of Foreign Investment In The Third World", UK, Routledge, 2000, pp 8. " FDI from developing and transition economies: Implications for development", UNCTAD World Investment Report 2006, available from http://www.unctad.org/ Templates/Page.asp?intItemID=1485\&lang=1, accessed 20 May 2011.

9 Ibid., 
For multinational firms in developing economies such as South Korea, significant drivers of overseas investment include small-size domestic market, rising domestic production costs, unfriendly domestic business environment, intense competition from local firms, and new incentives provided by potential host economies such as lower taxes. From the 1960s to the mid-1980s, Korea's FDI abroad remained insignificant and mainly focused on resource-seeking investments such as mining, forestry and trading businesses. For example, Korean OFDI in green field investment began with the forest development investment in Indonesia by Korea South Development Co. in $1968 .{ }^{10}$ For the manufacturing sector, labor intensive industries such as textile and clothing accounted for the largest share of the Korean manufacturing OFDI, up to the early 1990s. ${ }^{11}$

From the early 1990s, the local business environment in Korea experienced a sharp change with the reformation of government policies. Domestic problems such as substantial wage hikes (due to the improvement of labor welfare law), frequent labor disputes and appreciation of Korean won led Korean firms to invest overseas. ${ }^{12}$ To enhance the competitiveness of Korean firms while improving the labor rights, the Korean government reformed its overseas direct investment policy by encouraging Korean firms to invest overseas. Moreover, the changes in global markets such as rising protectionism in trade and technology, formation of economic blocs, and incentives offered by many overseas countries were also contributory reasons for foreign direct investment. ${ }^{13}$ The increase in FDI by Korean firms was specifically pointed out by KOTRA president- Cho Hwan-eik that 'Investing in foreign countries is a must for South Korean firms to explore new overseas markets and also secure energy and natural resources that are essential to their production while also maintaining their price competitiveness through global manufacturing systems' ${ }^{14}$ Expansion of global business by powerful Korean business groups such as Samsung, POSCO, Hyundai and LG also pushed the companies to exploit ownership advantage through FDI. OFDI has become a crucial corporate strategy of Korean MNCs to gain international competitiveness.

To attract investment from overseas, South East Asian countries that are rich in resources, offer huge incentives and have become attractive investment locations for Korean firms. This situation not only allows Korean firms to offset the disadvantages in the home country in terms of resources and labor cost, but also provides opportunities for market expansion.

10 K.H., Park, "External Factors Inducing Korean Overseas Direct Investment", The Journal of the Korean Economy, Vol. 1, No. 1, Spring 2000), pp 191-205.

11 H.C., Moon, “Outward Foreign Direct Investment By Enterprises From The Republic Of Korea, in Global Players From Emerging Market: Strengthen Enterprise Competitiveness Through Outward Investment", New York and Geneva, UNCTAD, 2007.

12 Sung C., Bae, and S.G., Hwang, "An Empirical Analysis Of Outward Foreign Direct Investment Of Korea And Japan", Multinational Business Review, 1525383X, Fall 97, Vol. 5, Issue 2,1997.

13 Ibid.

14 "Developing countries seek to attract South Korean investment", Bernama, 14 May, Available from http:/ / www.theborneopost.com/2011/05/14/developing-countries-seek-to-attractsouth-korean-investment/, accessed 9 June 2011, 


\section{Current status and trend of Korea's OFDI in South East Asia}

In the manufacturing sector, Korean outward foreign direct investment had already begun in 1974. However, the yearly outflow never exceeded US\$39 million during the 1970s; by the end of the 1970s, the cumulative sum was slightly above US\$126 million. ${ }^{15}$ Korean outward foreign direct investment began to rise sharply in the late 1980s following the rising domestic production cost. This spurred manufacturing companies to start relocating their factories abroad, particularly to South East Asian countries. In the 1980s, Korean foreign direct investment in the South East Asian region was concentrated in Indonesia, which accounted for $81 \%$ of Korea's total foreign direct investment in the region. Flow of Korean OFDI to South East Asia started to increase substantially from 1988, followed by steady up trend throughout the 1990s (see Figure 1). From 2004-2008, the investment value rose sharply particularly in Vietnam, Indonesia, Malaysia and Singapore; however it dropped drastically in 2009 due to the global financial crisis. Nevertheless, the sharp fall was only temporary as revealed by Figure 1. Korean overseas foreign direct investment caught up very quickly from 2010 onwards thanks to the market recovery.

Figure 1: Trend of South Korea's OFDI in South East Asia from 1980-2010

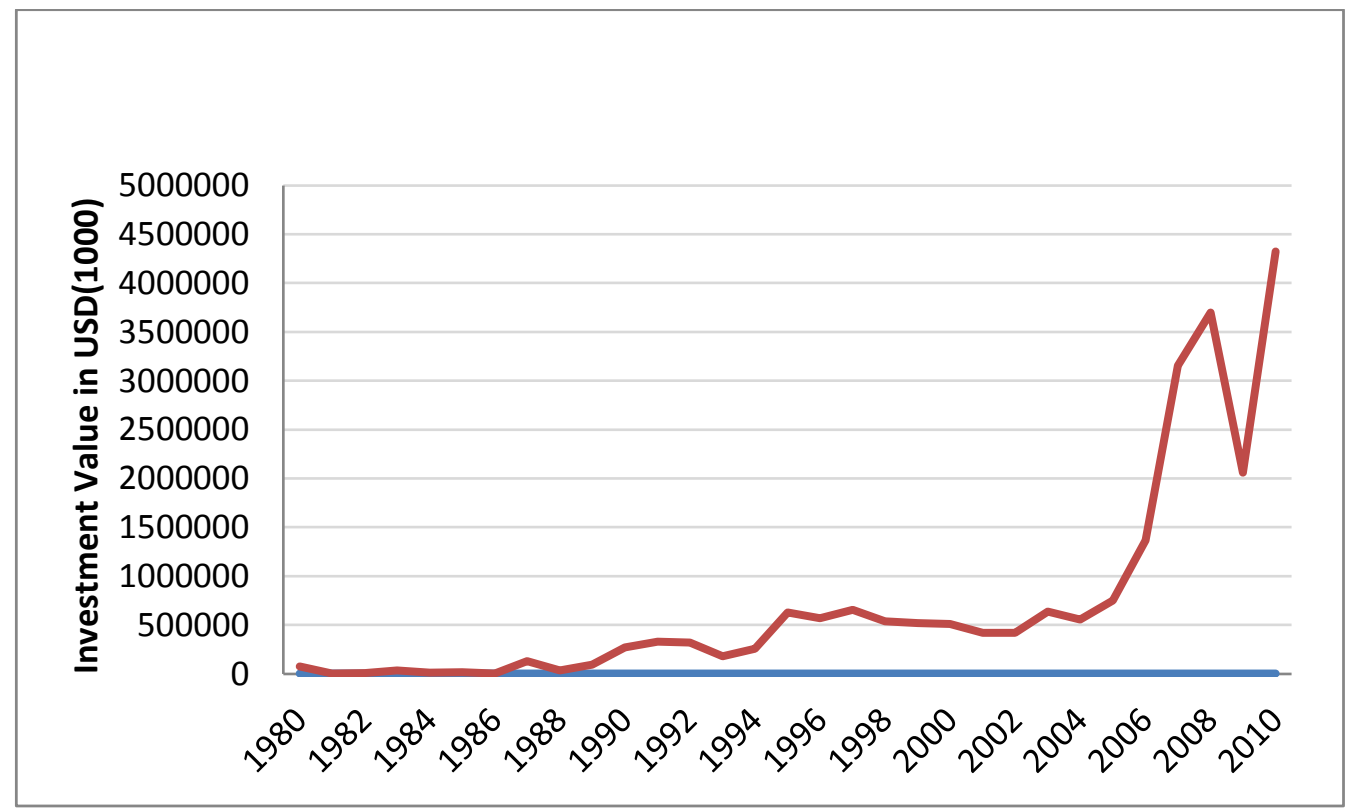

Source: Figure constructed from the source of Export-Import Bank of Korea

Based on the cumulative investment value in the period of 1968-2010, sourced from the Export-Import Bank of Korea, the largest FDI recipient country from Korean firms in Southeast Asia is Vietnam (28 \%), followed by Indonesia (21 \%), Singapore (15\%), Malaysia (13\%), Cambodia (7 \%), the Philippines (7\%), Thailand (5\%), Myanmar (3\%),

15 C.H., Lee, "Korea's Direct Foreign Investment in Southeast Asia", ASEAN Economic Bulletin, Vol.10.No.3 March 1994. 
Laos (1 \%) and Brunei $(0.32 \%)$. It is important to note that the FDI figure for Vietnam is calculated from 1992, and not 1968 as done for the other countries like Indonesia, Malaysia, Singapore, Thailand and the Philippines. This is because Vietnam's open door policy to foreign investment only began from the early 1990s which opened up the country for receiving FDI from foreign firms. Since then, Vietnam has started to overtake Indonesia as the most attractive investment location in South East Asia for Korean MNCs. Korean firms are attracted by Vietnam's potentially huge consumer market and its large pool of cheap labor. However, the main determining factor for the sudden shift of investment of Korean MNCs to Vietnam is the open-door policy. The foreign investment law in Vietnam was enacted in December 1987 and was amended in June 1990 and December 1992 to attract FDI under a more favorable legal environment. ${ }^{16}$ The similarities between Vietnamese and Korean culture is also another reason for the closer economic relationship. Both countries belong to Sinic-cultural zone, which share more similarities in cultural traditions and work values.

As of April 2010, Korea remained the biggest foreign investor in Vietnam with more than 2,495 projects worth US\$21.99 billion. ${ }^{17}$ Since the year 2000, investments of Korean MNCs in Vietnam have been increasing substantially. This makes Vietnam the largest recipient of Korean OFDI in South East Asia as shown by Figure 2.

Figure 2: Korea OFDI's Trend in Southeast Asia, by Country from 1980-2010

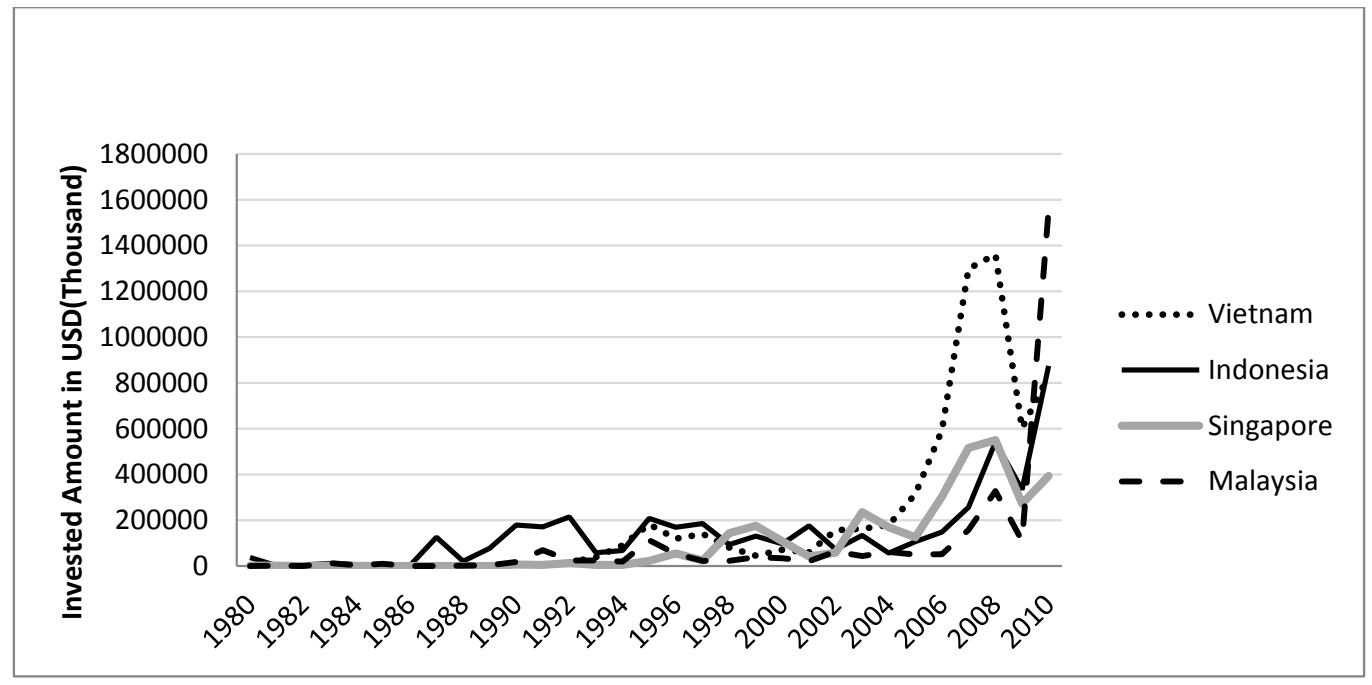

Source: Figure constructed from the source of Export-Import Bank of Korea

16 S.Y., Koo, "South Korea And The Transitional Economies Of Southeast Asia: A Case Study Of South Korea-Vietnam Economic Relations", in Daljit Singh and Reza Y.Siregar ed. "Asean And Korea: Emerging Issues In Trade And Investment Relations", Singapore, Institute of South East Asian Studies, 1995.

17 "ROK Biggest Foreign Investor in Vietnam", Vietnam Business Asia, 14 June 2010, available from http:/ / vietnambusiness.asia/rok- \% e2\%80\%93-biggest-foreign-investor-in-vietnam/, accessed 5 May 2011. 
Korea's OFDI in South East Asia is concentrated in four countries- Vietnam, Indonesia, Singapore and Malaysia, which accounted for about $77 \%$ of total cumulative investment from 1968-2010. Korean firms mainly invested in the manufacturing industry, which accounted for $46 \%$ based on the cumulative investment value from 1968-2010 (see Figure 3).

Figure 3: Korea's OFDI in South East Asia, by Industry (1968-2010)

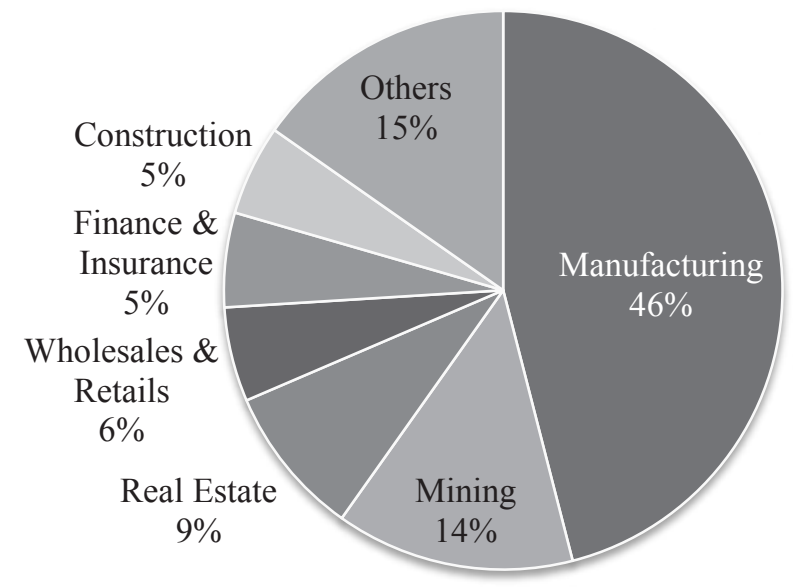

Source: Figure constructed from the source of Export-Import Bank of Korea

Other major industries that have received large amount of investments from Korean firms include mining, real estate and property, finance and insurance service, wholesale and retail and construction. Figure 4 shows the Korean OFDI in Southeast Asia by country and period.

Figure 4: Korea's OFDI in South East Asia by Country and by Period

Figure 4.1 OFDI from 1968-1989

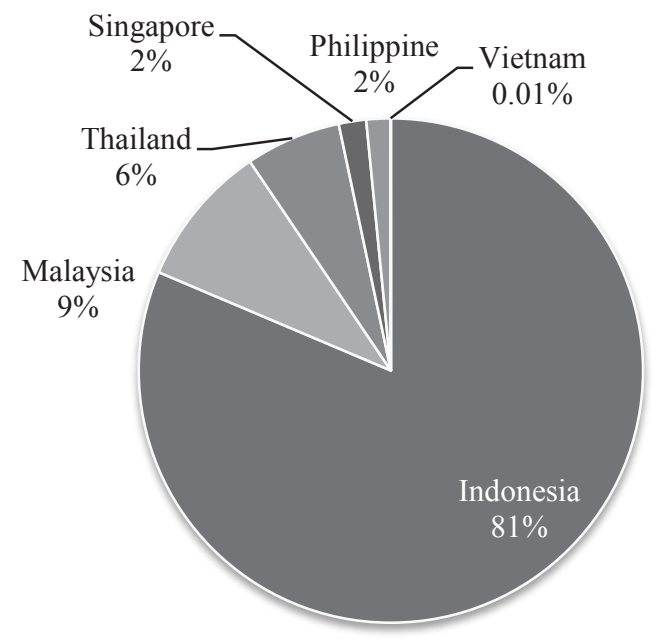

Figure 4.2 OFDI in 1990s

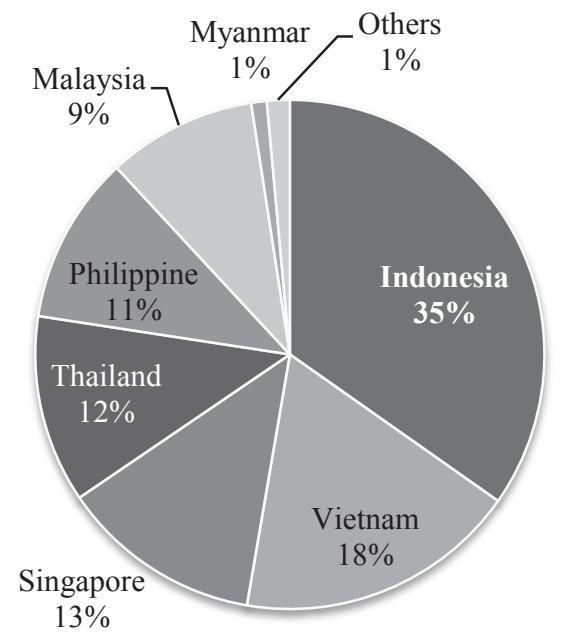


Figure 4.3 OFDI from 2000-2010

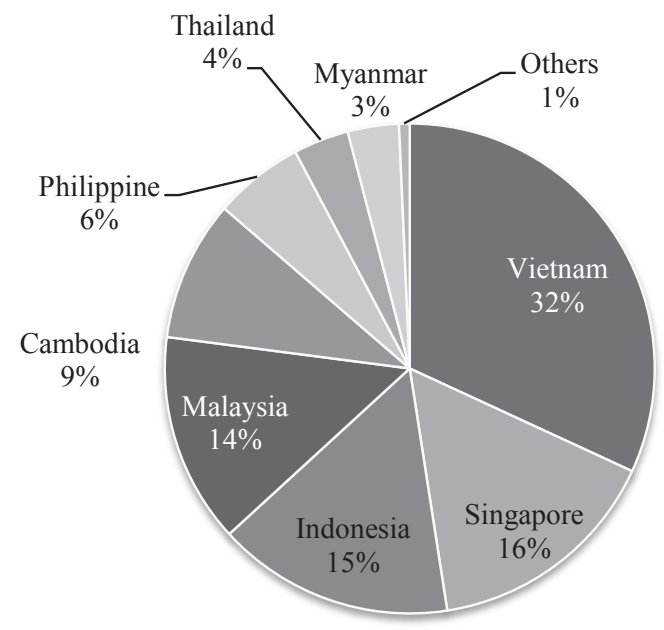

Figure 4.4 Cumulative OFDI from 1968-2010

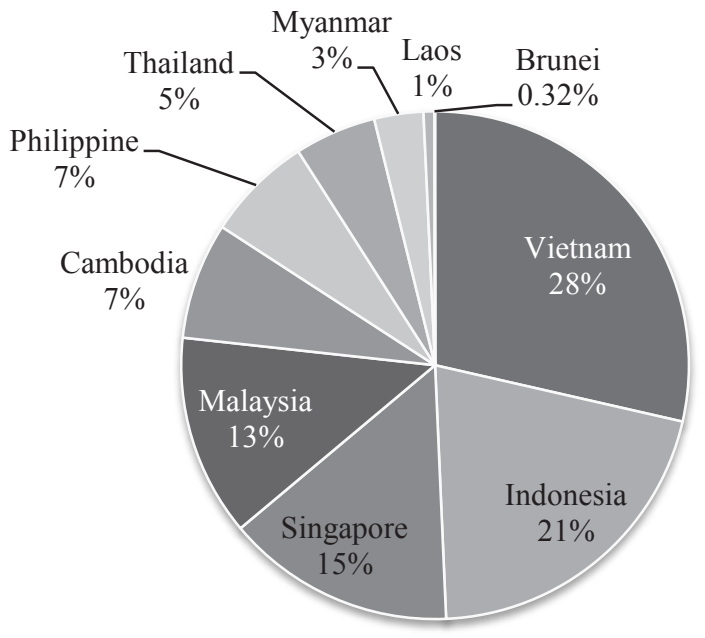

Source: Figure constructed from the source of Export-Import Bank of Korea

\section{Motivation of Korean MNCs investments in South East Asia and case studies}

The theory suggests that flows of FDI into neighboring countries (the region) are a common characteristic, especially in the initial stage of MNC's development. This is due to familiarity, ease of access, cross-border spillovers and other identical factors. ${ }^{18}$

Figure 5: Motivation of South Korea's FDI in South East Asia from 1990-2010

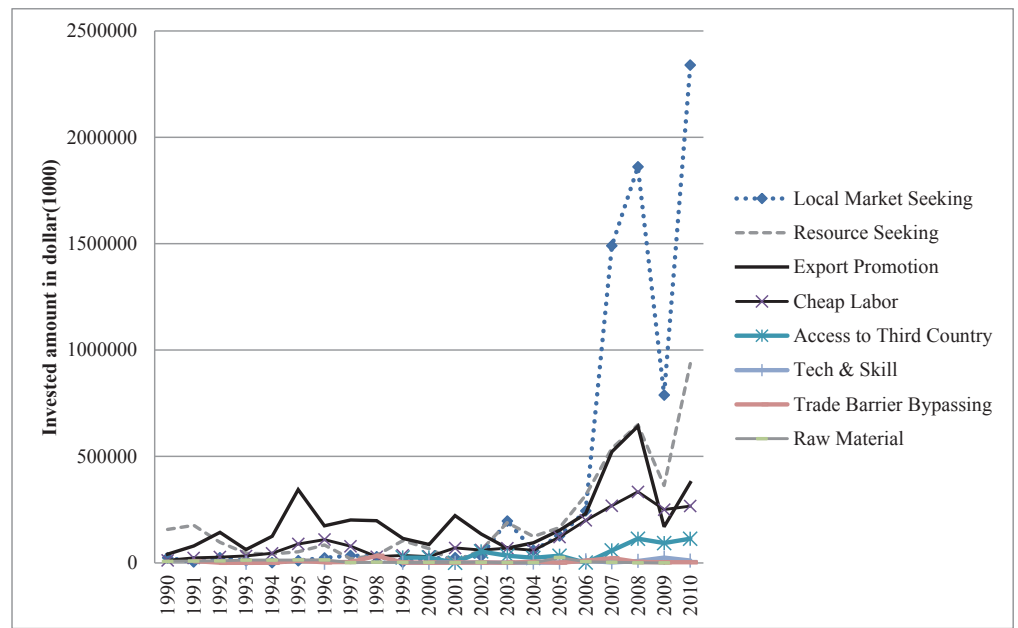

Source: Figure constructed from the source of Export-Import Bank of Korea

18 UNCTAD, “FDI From Developing And Transition Economies: Implications For Development”, World Investment Report 2006, Available from http://www.unctad.org/Templates/Page. asp?intItemID=1485\&lang=1, accessed 20 May 2011. 
The Southeast Asian region, which is located quite near to South Korea, offers attractive destinations for investments. Due to the disadvantages of Korea in terms of small domestic market size, scarce natural resources and lack of cheap unskilled labor, Korean firms sought to exploit the advantages of the Southeast Asian countries. Based on the source of the Export-Import Bank of Korea, market seeking and resources seeking were the major motivations for Korean MNCs to invest in Southeast Asia

Up to the 1980s, Korea's OFDI in Southeast Asia was concentrated on resourceseeking FDI, particularly in Indonesia, which had attracted $81 \%$ of total Korean investment in Southeast Asia. However, market-seeking FDI (local market and export promotion) has risen noticeably from the 2000s (see Figure 6). Southeast Asia, with a population of approximately 590 million people, accounting for $8.8 \%$ of the world population, offers a huge market for Korean business firms.

Figure 6: Motivation of Korea's OFDI in Southeast Asia, by Period

Figure 6.1 Motivation of FDI in 1990s

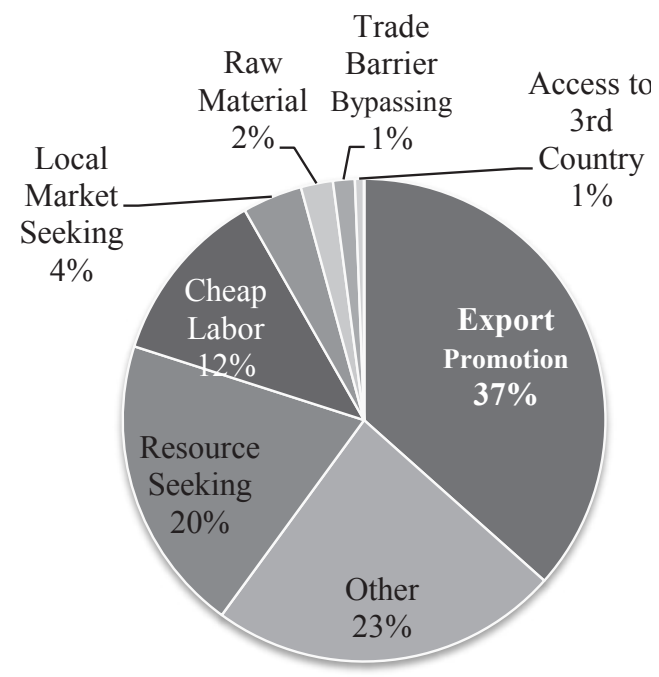

Figure 6.2 Motivation of FDI in 2000s

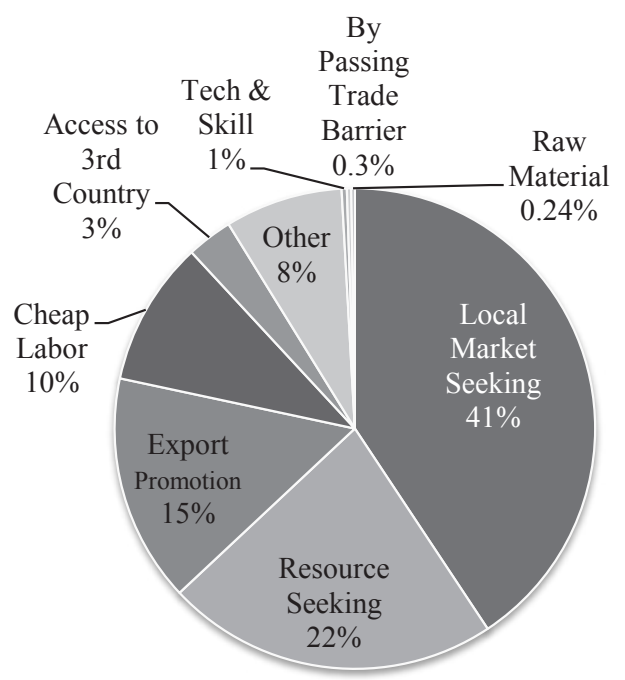

Source: Figure constructed from the source of Export-Import Bank of Korea

The rapid growth of the economy in Vietnam, Indonesia, Singapore, Malaysia and Thailand provides vast business opportunities for Korean firms. Based on the data of the Export-Import Bank as indicated in Figure 7, Southeast Asian countries that have attracted a great deal of market-seeking FDI include Singapore and Malaysia. Most of the resource seeking and cheap labor seeking FDI are channeled into Vietnam and Indonesia. Compared to Singapore and Malaysia, Vietnam and Indonesia are able to provide lower-cost labor as well as cheaper raw material. In fact, many Korean SMEs have invested in labor-intensive manufacturing industries in these two countries. Apart from being more competitive in terms of industrial production cost, Vietnam and Indonesia are also richer in natural resources and have bigger domestic markets. Thus, it is not surprising to see almost half of FDI 
in Vietnam and Indonesia are motivated by resource and cheap labor seeking in the past two decades (see Figure 7). However, the shortage of labor in some provinces of Vietnam, (e.g., Binh Duong) in recent years has made it a less attractive location for labor-intensive projects such as textiles, garment and footwear. Sharp rise of inflation and low wages have caused a number of labor strikes in Vietnam and the problem has led to shortage of labor.

Based on a survey of Vietnam General Confederation of Labour, done in late November 2010 among 2,100 laborers in seven cities and provinces, only a minority of the respondents (3.9\%) felt satisfied with their salaries while about half of the respondents $(50.9 \%)$ were unsatisfied with their salaries. ${ }^{19}$ To solve the labor issues, the Vietnamese government encouraged investors to venture into high tech, electronics, and engineering industries as well as service projects such as hotels, entertainment parks, golf, housing, banking, education and health care. The gradual change in investment environment is causing a shift in the motivation trend of Korea's FDI in the region. Choong-Shik Kang, Chairman of the Korean Chamber of Commerce and Industry (Kocham) in HCMC, said that, 'Korean companies had previously invested in light industries, such as producing footwear and garments, to make use of Vietnam's advantage of cheap labor. They are now moving out of that comfort zone as conditions change'. ${ }^{20}$

Figure 7: Motivation of Korea's OFDI in Southeast Asia by Country (Cumulative Investment Value)

Figure 7.1 Vietnam( 1992-2010)

Figure 7.2 Indonesia ( 1968-2010)
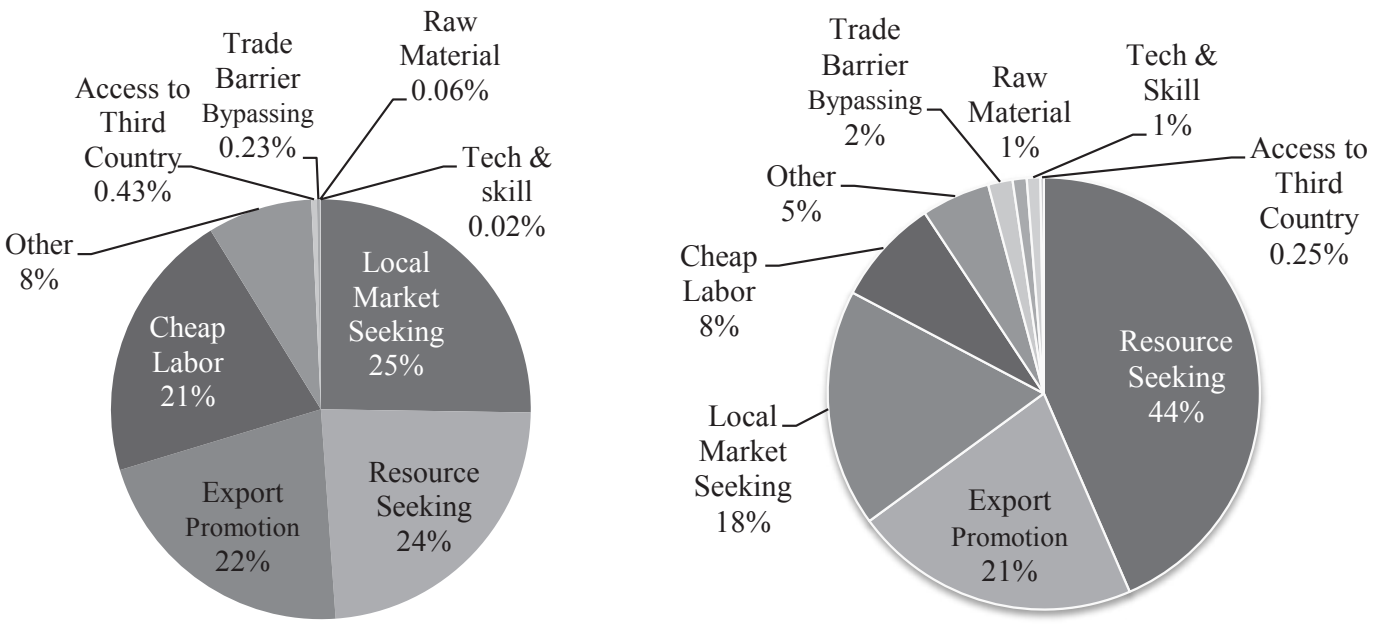

\footnotetext{
19 "IP Workers Get the Hump", Vietnam Business Asia, 9 June 2011, available from http:// vietnambusiness.asia/ip-workers-get-the-hump/, accessed 9 June 2011.

20 "South Korea Investors Now Shifting to Heavy Industry", Vietnam Business and Economy News, 4 January 2011, available from http:/ / www.vneconomynews.com/2011/01/south-koreasinvestors-now-shifting-to.html, accessed 9 June 2011.
} 
Figure 7.3 Singapore (1968-2010)

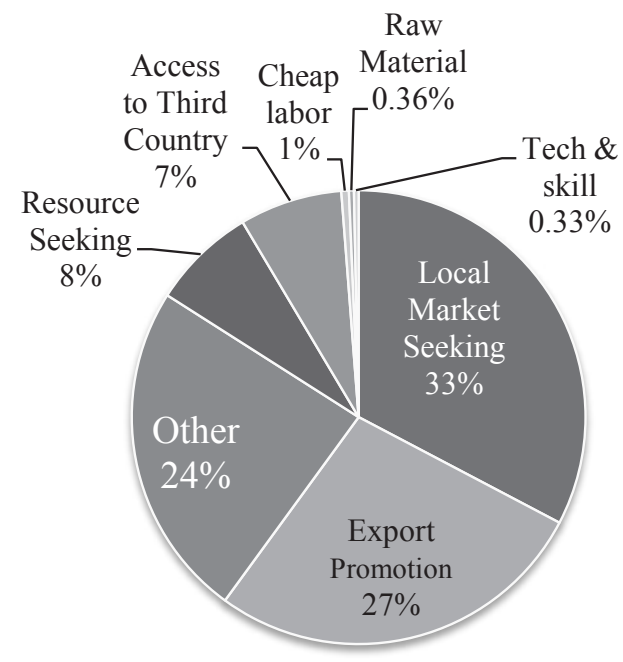

Figure 7.4 Malaysia (1968-2010)

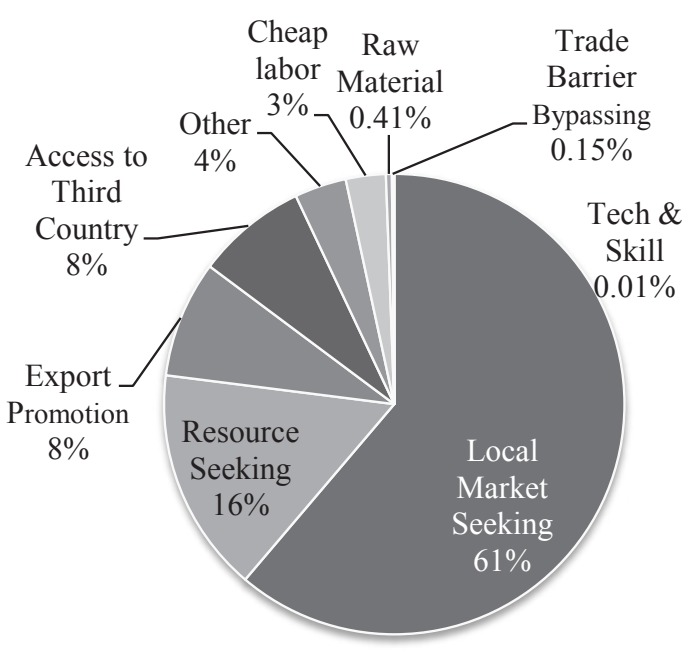

Source: Figure constructed from the source of Export-Import Bank of Korea

The changes in investment pattern explain the difference between the current motivations of Korean FDI in the region and those from the past. Previously, resource-seeking and efficiency-seeking investments occupied the major position; currently the market-seeking investments are gradually taking over as the leading FDI in countries of the region, including for Indonesia and Vietnam.

\section{Market seeking}

Market seeking is a primary determinant of FDI for many international firms. In order to promote sales in the international market, setting up of local or regional offices is one of the significant approaches. It allows a firm to reduce cost, better adapt products for the local market, be easily accessible by customers, and bypass trade barriers. Marketseeking FDI is a crucial international business strategy to boost company sales overseas. Since the year 2000, an increasing number of Korean firms have invested in Southeast Asia with the purpose of market expansion. Based on the latest statistics of the ExportImport Bank of Korea, market-seeking FDI outstripped other types of FDI as the most significant motivation of Korean MNCs investment in Southeast Asia in recent years as revealed in Figure 5. For instance, SK Telecom has invested US\$116 million in Malaysia in 2010 for its business expansion in the Southeast Asian region. Samsung Electronics has also successfully moved up its market position in the region through FDI strategy.

\section{Case 1- Investment of Samsung Electronics in Southeast Asian Countries}

Samsung Electronics has invested vastly in South East Asia, holding investments across six Southeast Asian countries. The huge market potential of the Southeast Asian region is one of the main reasons for the investments of Samsung Electronics. 
Samsung's current investments in the region consist of seven sales operating offices for consumer electronics business and seven production bases, which are situated in Indonesia, Malaysia, the Philippines, Thailand and Vietnam. ${ }^{21}$ The regional headquarters for Samsung in Southeast Asia and Oceania is located in Singapore. December 1990 marked the establishment of the sales subsidiary of Samsung in Singapore, called the Electronics Business Division (Consumer Electronics, Telecommunications, IT). The hub for Samsung's regional memory business, procurement and customer service is also situated in Singapore. ${ }^{22}$

By investing in Southeast Asia, Samsung aims to strengthen its presence and brand value in the regional market. Samsung Electronics is involved in the whole range of activities, which include digital media, LCD, semiconductor, telecommunication network and digital appliance. ${ }^{23}$ During the period from January to May 2009, Samsung had the largest market share in six Southeast Asian countries -- Indonesia, Malaysia, Thailand, Vietnam, the Philippines and Singapore for LCD TV sales. ${ }^{24}$ During the fivemonth period, Samsung's market share was as follows: 36 per cent in Vietnam, 38 per cent in the Philippines, 36 per cent in Thailand, 28 per cent in Indonesia, 22 per cent in Malaysia and 27.8 per cent in Singapore..$^{25}$

Besides the strong market position of LCD TV, Samsung's mobile sales in the region were growing rapidly. By the year 2007, Samsung Mobile ranked the second largest mobile company in South East Asia. With the aim of further establishing its mobile phone market position in South East Asia, Samsung in the year 2009 invested millions of dollars to build a handset plant in BacNinh, Vietnam. Currently, Samsung Vietnam is operating a US $\$ 670$ million mobile phone and camera factory in BacNinh. ${ }^{26}$ In 2011, the revenue of Samsung's factory in BacNinh was US\$5.8 billion. The company expects the export turnover to reach US $\$ 16$ billion in $2015 .{ }^{27}$ In fact, Samsung increased the investment in its Vietnam's handset plant during the past years. This was part of its strategy to compete more effectively with Nokia in the global market by taking higher market share in the Asian emerging markets, which included Malaysia, Indonesia and Vietnam. ${ }^{28}$ Cell phones produced in Samsung's Vietnam plant enabled Samsung to enter the South East Asian market with a lower tariff rate. The product was subject to only 5 per cent tariff for export to other ASEAN member countries. When a Samsung

${ }_{21}$ Samsung, "2009 Sustainability Report", available from http://www.samsung.com/my/ aboutsamsung/citizenship/oursustainabilityreports.html, accessed 21 June 2011.

22 Samsung, "2011 About Samsung", available from http://www.samsung.com/ sg/aboutsamsung/samsungelectronics / businessarea / CompanyProfile_ SAMSUNGElectronicsInSingapore.html, accessed 5 June 2011.

23 Ibid.

24 "Samsung Electronics tops LCD TV sales in South Asia", Asia Pulse, 14 July 2009, available from http:/ / www.antaranews.com/en/news/1247537453/samsung-electronics-tops-lcdtv-sales-in-south-asia, accessed 20 June 2011.

25 Ibid.

26 "Samsung sets R\&D Operation in Vietnam", UNIBROS, 11 January 2012, available from: http://www.uni-bros.com/en/news.php/samsung_sets_rampd_operation_in_vietnam/ id=20182/ cid=3, accessed April 102012.

27 Ibid.

28 "Korean firms win big coal deal in Indonesia", Korea Times, 16 September 2008, available from http://www.koreatimes.co.kr/www/news/biz/2008/09/123_31105.html, accessed 12 May 2011. 
official was interviewed in 2008, the official said that, 'In order to achieve the yearly target of 200 million and increase our global market share, we should not lose Southeast Asia, where Nokia is relatively weak...we will expand our production to 100 million in a few years in response to the growing demand for handheld devices in Southeast Asia' ${ }^{29}$ The Vietnam plant is part of Samsung's investment strategies to expand in the medium and low-cost phone market. In 2012, Samsung has successfully overtaken Nokia to become the world's biggest handset maker. The outstanding sales performance reflects the successful investment strategy of Samsung Electronics in South East Asia.

\section{Case 2- SK Telecom investment in Malaysia}

SK Telecom, a leading mobile service provider in Korea has invested US\$116.5 million in a Malaysian telecom company- Packet One Networks Sdn Bhd ("P1") in 2010. By forming a strategic alliance with P1, SK Telecom holds approximately $26 \%$ of P1 shares, which is equivalent to US $\$ 116.5$ million. ${ }^{30}$ The strategic alliance is seen as a win-win strategy for both firms where P1 benefited from SK Telecom's network, operational management experience and its global procurement resources. At the same time, SK Telecom is able to strengthen its market position in South East Asia.

The initial investment of SK Telecom was US $\$ 100$ million in June 2010, and RM50.5 million (US\$16.5mil) was further invested in 2011 to support the network expansion of P1. ${ }^{31}$ P1 Chief Strategy Officer cum Deputy Chief Executive Officer Dr Ahn Hoe Kyun, the representative from SK Telecom in P1, stated that, 'We are very interested to increase our shares in P1 going forward...our presence in Malaysia with P1 will be crucial to expand our business in South East Asia'. ${ }^{32}$ Ki Haeng Cho, President of SK Telecom's GMS CIC (Company In Company) also commented, 'The Malaysian market has great potential for growth and the partnership with P1, the leading WiMAX provider of Malaysia, is an extremely attractive opportunity for SK Telecom. The alliance will allow SK Telecom to rise as a global telecommunications company based on its cutting edge technology and innovative marketing tools. ${ }^{33}$

While investments in P1 helped SK Telecom to expand its market, P1 benefited from technology and management expertise transfer. As pointed out by CC Puan, Group Managing Director and CEO of Green Packet Berhad, 'P1's strategic alliance with

29 Ibid.

30 "P1 Gets Us\$100 Million Investment \& Expertise Of Korea's Leading Global Telco: Forms Strategic Alliance with SK Telecom to Advance WiMAX in Malaysia", P1 WiMax Press Report, 29 May 2010, available from http://www.p1.com.my/pressreleases/29062010_P1_Gets_ US100Million.htm, accessed 22 May 2011.

31 "Green Packet, S.Korea telco plan RM201m investment in P1", The Star, 17 May 2011, available from http:/ / biz.thestar.com.my/news/story.asp?file=/2011/5/17/business/2011051707460 0\&sec=business, accessed 10 April 2012; " SK Telecom ups investment in Malaysian wireless operator", Yonhap News, 16 May 2011, available from:http://english.yonhapnews.co.kr/ news/2011/05/16/6/0200000000AEN20110516006200320F.HTML, accessed 5 June 2011.

32 "Green Packet, S.Korea telco plan RM201m investment in P1", The Star, 17 May 2011, available from http:/ / biz.thestar.com.my/news/story.asp?file=/2011/5/17/business/201105170746 00\&sec=business, accessed 10 April 2012.

33 "P1 Gets Us\$100 Million Investment \& Expertise Of Korea's Leading Global Telco: Forms Strategic Alliance with SK Telecom to Advance WiMAX in Malaysia", P1 WiMax Press Report, 29 May 2010, available from http://www.p1.com.my/pressreleases/29062010_P1_Gets_ US100Million.htm, accessed 22 May 2011 
SK Telecom will significantly enhance P1's ability to serve the Malaysian broadband user needs with 4G WiMAX technology. Moreover, having access to SK Telecom's expertise as a leading global Telco supports our strategic agenda to be the leading $4 \mathrm{G}$ WiMAX Telco in Malaysia and eventually in the region. Korea is the leading example of a country rising from a low level of ICT access to one of the highest in the world... Through this alliance, Malaysia as a nation can draw from this experience in pursuing its own broadband penetration goals' ${ }^{34}$ Michael Lai, CEO of P1 also commented that, 'Our partnership with SK Telecom will not only help expedite our nationwide WiMAX rollout to reach $65 \%$ population coverage by 2012, but will also contribute to our key priorities of optimizing our network and customer satisfaction, further enabling us to deliver high quality broadband to all Malaysians' ${ }^{35}$ Briefly, the strategic partnership between SK Telecom and P1 benefits both parties; it allows SK Telecom to expand its market in South East Asia, while P1 benefits from capital, technology and skill transfer.

\section{Efficiency seeking}

A multinational firm is deemed to be making an efficiency-seeking investment when it invests in a country to save input costs, particularly labor. Thus, most of the efficiencyseeking investments are concentrated in labor-intensive industries that mostly involve electrical and electronic products, garments and IT services. Among the Southeast Asian countries, Indonesia and Vietnam have attracted a large amount of efficiency-seeking investments from Korean firms. The abundance of cheap labor in these two countries have matched Korea's search for alternative sources of low-cost labor. For instance, the current Vietnamese average minimum wage is three times less compared with other ASEAN countries. ${ }^{36}$ The current Vietnamese minimum wage in terms of purchasing power parity is \$85 a month, compared with \$148 in Indonesia, \$295 in Thailand and $\$ 379$ in the Philippines. ${ }^{37}$ Although the minimum monthly wage was raised to 830,000 dong from 730,000 dong, from 1st May 2011 onwards, it is still considered low compared with its neighboring countries. It is evident that the low wages of Vietnamese workers has been the major factor for attracting Korean MNCs to invest in Vietnam for the past two decades. Due to large investments from South Korea, Korea is the largest foreign investor in Vietnam. According to Kocham in HCMC, there are some 2,500 South Korean businesses operating in Vietnam, including 1,253 businesses in the Central and Southern Vietnam. ${ }^{38}$ Besides Vietnam, Indonesia is also another important location for Korean efficiency-seeking investments in South East Asia. There are currently over 2,500 Korean companies operating in Indonesia and more than 30,000 Korean people domiciled in Indonesia; they are the largest foreign community residing in the country. ${ }^{39}$ The majority of Korean investors in Indonesia are running SMEs, which involve labor-

34 Ibid.

35 Ibid.

36 "IP Workers Get the Hump", Vietnam Business Asia, 9 June 2011, available from http:// vietnambusiness.asia/ip-workers-get-the-hump/, accessed 9 June 2011.

37 International Labor Organization, cited in China Daily, 6 April 2011.

38 "South Korea Investors Now Shifting to Heavy Industry", Vietnam Business and Economy News, 4 January 2011, available from http:/ / www.vneconomynews.com/2011/01/south-koreasinvestors-now-shifting-to.html, accessed 9 June 2011.

39 "Bilateral relations taking off", Korea Times, 16 August 2009, available from http:/ /www. koreatimes.co.kr/www/news/special/2009/10/211_50213.html, accessed 3 June 2011. 
intensive manufacturing industries like textile, garment, foot ware, toys, plastic ware, etc. ${ }^{40}$ The following two case studies are examples of efficiency-seeking investments by Korean firms in South East Asia.

\section{Case 1- Korean HanSoll Textiles Co. LTD in South East Asia}

Korean HanSoll Textiles, a small and medium enterprise in the textile industry has invested heavily in the South East Asian countries. HanSoll's core business is knitted and crocheted apparel, and also involved in wholesale of shirts and outer garments. ${ }^{41}$ Currently Hansoll Textiles Co. LTD has four factories in Vietnam, three factories in Indonesia, four factories in Cambodia and one factory in the Philippines. ${ }^{42}$ As HanSoll Textiles is in a labor-intensive industry, the abundance of cheap labor and relatively low production cost in these four countries are the main reasons for its investments. HanSoll Textiles now employs more than 31,100 employees in the region, which comprise 11,350 employees in Vietnam, 11,150 employees in Indonesia, 7,100 employees in Cambodia and 1,500 employees in the Philippines. ${ }^{43}$ HanSoll Textiles established its first factory in South East Asia in 1997 in Indonesia Jawa Barat, and the number was later increased to 14 factories in the region. ${ }^{44}$ License for a period of 44 years has been granted to HanSoll Vina to operate a garment factory in Song Than Industrial Park, located in Binh Duong province of Vietnam. Concerning the company's products, more than $90 \%$ are for export purpose, while the remaining products are retained for domestic use. Although the initial purpose of the investment was for promoting export, the local sales in the region have also increased significantly in recent years. For instance, the company's sales in Vietnam increased to US\$233 million in 2011 from US\$162 million in 2009. In Indonesia, sales rose from US\$196 million in 2009 to US\$323 million in $2011 .^{45}$ These figures show that the investments in Southeast Asia did not only benefit from low production cost but also promoted regional sales.

\section{Case 2- Investment of South Korean garment makers- Sae-A in Indonesia}

South Korean-based textile and garment manufacturer Sae-A views the South East Asian region as an attractive investment location for production of textile and garments. The company has more than 20 factories globally, including those in Indonesia and Vietnam. It is a manufacturer of clothing and textiles supplying to the world's top clothing brands such as Gap, Banana Republic and Levi's. Cheap labor and raw materials in Indonesia and Vietnam are important reasons for Sae-A to set up its factories in this region. In Indonesia, Sae-A operates two factories both in West Java, with approximately 10,000 workers being employed at the Purwakarta and Sukabumi

\footnotetext{
40 Ibid.

41 "KIS Korea Company Profile Plus 2011", Company Profile of Hansoll Textile Co.,LTD, 4 April 2011, NICE Information Service Co. Ltd.

42 Hansoll Textile Co. Ltd, 2012, "Company information-overseas factories", available from http://www.hansoll.com/english/company, accessed April 302012.

43 Ibid.

44 Ibid.

45 Ibid.
} 
factories. ${ }^{46}$ The latest investment by Sae-A in Indonesia was in 2010, which was the building of a textile plant in Jatiluhur, West Java. The company operates an integrated textile plant with an investment of $\$ 200$ million, and is expected to employ up to 15,000 workers. ${ }^{47}$ The plant occupies a 60 -hectare site in Jatiluhur, about 2 hours drive from Jakarta. For labor-intensive industries like textile, maintaining low production cost is crucial for sustaining competitiveness. Thus, it is not surprising to see Sae-A investing heavily in South East Asia.

\section{Resources seeking}

Korea, a country that is short of natural resources, has to seek business opportunities in the Southeast Asian region to offset the disadvantages in its own country. Resourceseeking FDI strategies have been pursued by manufacturing companies that rely extensively on raw materials for their products (e.g., furniture and paper manufacturers). This strategy involves moving production to a foreign site where essential raw materials are located, or by importing the materials to the factories in their home country. ${ }^{48}$ With the recent global race of securing resources in oil and gas, South East Asian countries rich in natural resources have started to attract more investment interest from Japan and Korea in energy and mining sector; both countries are eager to secure resources to fuel their economic growth. For instance, leading energy companies in Korea such as SK Corp. and Korea National Oil Corp have invested heavily in South East Asia for oil and gas; among the countries targeted for investment are Indonesia and Vietnam. Particularly for Indonesia, resource sector has been the most attractive investment area for Korean firms. For example, from 1968-2010 resource-seeking investments accounted for $44 \%$ of Korean OFDI to Indonesia (see Figure 7.2). Most of Korea's OFDI to South East Asia during the 1980s and 1990s had been attributed to resource-seeking investments.

\section{Case 1-KEPCO and Inni-Korea Resource in Indonesia}

Among the Korean firms, government-owned electric power company Korea Electric Power Corp. (KEPCO), which is responsible for the major supply of electric power in Korea, is expanding its electricity and natural resources business in Indonesia. The company aims to win bids for electric power generation and natural resources development projects in Sumatra, Kalimantan and Java. ${ }^{49}$ In 2007, KEPCO successfully gained an investment project in Kalimantan, where a memorandum of understanding

46 "South Korean firm building \$200m textile plant in West Java", Jakarta Post, 12 February 2010, available from http:/ / www.thejakartapost.com/news/2010/02/12/s-korean-firm-building200m-textile-plant-west-java.html, accessed 4 June 2011.

47 "Sae-A to build \$200 Million textile plant in West Java", Bloomberg Business Week, 12 February 2010, available from http:/ / investing.businessweek.com/research/stocks/ private/snapshot. asp?privcapId=50915564, accessed 14 May 2011.

48 UNCTAD, "FDI From Developing and Transition Economies: Implications For Development", World Investment Report 2006, Available from http://www.unctad.org/Templates/Page. asp?intItemID=1485\&lang=1, accessed 20 May 2011.

49 "KEPCO to expand business in Indonesia", Korea Times, 25 November 2007, available from http://www.koreatimes.co.kr/www/news/biz/2010/08/123_14347.html, accessed 8 June 2011. 
(MOU) was signed between the company and Indonesian firm-Nuansa. ${ }^{50}$ KEPCO's plans also include acquiring gas field projects in Indonesia, particularly in the West Java. In 2011, a feasibility study for a $\$ 2$ billion project was proposed by the firm..$^{51}$ The scope of the project included construction of small and medium-sized gas fields, compressed natural gas (CNG) transport facilities and a 750-megawatt power plant in Banten province. ${ }^{52} \mathrm{KEPCO}$ also invested in Indonesia's coal mining industry to increase its coal self-sufficiency rate. For example, in 2010 KEPCO bought a 20 per cent stake in Bayan Resources in Indonesia. This purchase allows the company to secure two million tons of coal a year from 2012 and seven million tons annually from $2015 .{ }^{53}$ In 2009, KEPCO also acquired a 1.5 per cent stake in Indonesia's Adaro Energy, the second largest coal producer in Indonesia.

This acquisition enables the firm to secure three million tons of coal annually. ${ }^{54}$

In coal mining industry, Inni-Korea Resource is another Korean firm that has successfully won an Indonesian project on coal mine exploitation. In 2008, Inni-Korea Resource signed a memorandum of understanding with three Indonesian companies for the exploration of a 50,000-hectare mining area in Kotabaru County, Southern Kalimantan. ${ }^{55}$ The mines are believed to contain 3.8 billion tons of coal deposits. ${ }^{56}$ As the winner of the project, Inni-Korea Resource agreed to form a joint venture with its Indonesian partners for the development of infrastructure and preparation of production; it would invest $\$ 50$ million in the first stage of the project. ${ }^{57}$ The investment in coal mining is particularly important because Korea has been importing coal from Indonesia for several years. For instance in 2007, 20 \% of coal imports in Korea were from Indonesia. ${ }^{58}$ Through the investments of Inni-Korea Resource and KEPCO, Korea is able to secure stable coal supply from Indonesia, which is crucial for meeting the growing demands of Korean local industries.

\section{Case 2: Energy Investment by Korea National Oil Corp. and SK Corp. in Vietnam}

As a country rich in natural resources, Vietnam has received energy investments from Korean firms. Major Korean energy companies- Korea National Oil Corp (KNOC) and

50 Ibid.

51 "Korea Energy Firms to Invest \$2bln in Indonesia gas, power", Reuters, 30 June 2011, available from http://uk.reuters.com/article/2011/06/30/indonesia-kepcoidUKL3E7HU0H920110630, accessed 30 March 2012.

52 Ibid.

53 "KEPCO to invest \$512 million in Bayan Resources," Reuters, 21 July 2010, available from http://www.reuters.com/article/2010/07/21/kepco-indonesia-idUSSUL00011520100721, accessed 2 May 2012.

54 "Korea Electric Powers Buys into Indonesian Coal Producer" Yonhap News, 23 July 2009, available from: http:/ / english.yonhapnews.co.kr/news/2009/07/23/0200000000A EN20090723005800320.HTML, accessed 2 May 2012.

55 "Korean earns qualified coal concession in Kalimantan", AP Indonesia, 15 September 2008, available from http:/ /apindonesia.com/new/index.php?option=com_content\&task=view \&id=1943\&Itemid=65, accessed 8 June 2011.

56 "Korean firms win big coal deal in Indonesia", Korea Times, 16 September 2008, available from http://www.koreatimes.co.kr/www/news/biz/2008/09/123_31105.html, accessed 12 May 2011.

57 Ibid.

58 Ibid. 
SK Corp. are the main investors of energy in Vietnam. KNOC started its commercial production in Dec 2006 at the Rong Doi oil field, located 280 kilometers off the coast of the Vung Tau region. ${ }^{59}$ Only Korean technologies and capital are employed in this development project of gas field. According to KNOC, the Vietnam 11-2 block is expected to have an annual capacity of 47.5 billion cubic feet of natural gas and 1.53 million barrels of condensate; this will rake in net earnings of about USD 0.5 billion for the firm over the next 23 years. ${ }^{60}$

The second investment is by SK Corp., which purchased a 25 per cent stake in an offshore oil development project in Vietnam in 2007. The purpose of this investment was to meet the fast-growing energy demand in Southeast Asia as well as for the Korean market. SK acquired the shares in the 15-1/05 oil field from Vietnam's state-run oil monopoly, Vietnam Oil and Gas Corp., also known as Petro Vietnam. ${ }^{61}$ In November 2009, crude deposit located 180 kilometers southeast of Ho Chi Minh City was discovered by SK Energy (MENAFN 2009). This discovery signified the second time that the South Korean energy company had found oil in Vietnam. It had previously discovered oil deposit in the 15-1 block located nearby, in cooperation with Korea National Oil Corp. ${ }^{62}$ In overall, the overseas investment in mineral resources is crucial for Korean MNCs to secure stable supply and to fuel the economic growth of Korea.

\section{Conclusion}

Based on the current trend and the case studies, Korea's outward foreign direct investments in Southeast Asia are expected to rise in the coming years. The substantial increase in Korean firms' investments since the 2000s augurs well for the economy of countries in Southeast Asia as well as for Korean MNCs business growth. From big conglomerates, (e.g., Samsung, LG, KEPCO, S.K, Hyundai, etc.) to SMEs, Korean firms have continued to show strong interest to invest in Southeast Asia. Market-seeking investments in particular, are very dynamic. Korean firms have found that through foreign direct investment in Southeast Asia, they are not only able to strengthen the production efficiency, but also expand the overseas sales and promote export. The positive results of FDI in boosting sales and efficiency have convinced more companies to invest further. The recent big investment projects include the $\$ 6$ billion investment project by steel maker POSCO in Indonesia, SK Telecom's investment in Malaysia and investment of Hanjin Heavy Industries and Construction Company in shipyard building in the Philippines. In short, each country in Southeast Asia has its unique characteristics and attractiveness to Korean firms. Singapore, as a business hub in the region, is well- positioned as the regional hub for trade with Korea. The country

59 "Korea National Oil commences production at Vietnam gas field", Asia Pulse, 17 November 2006, available from http:/ / www.highbeam.com/doc/1G1-154581410.html, accessed 20 May 2011.

60 KNOC 2011 Korea National Oil Corporation (KNOC), "Business performance", available from http://www.knoc.co.kr/ENG/sub04/sub04_1_1.jsp, accessed 1 June 2011.

61 "SK Corp. buys stake in Vietnam offshore oil field" Maritime Reporter, 12 February 2007, available from http://marinelink.com/news/article/sk-corp-buys-stake-in-vietnamoffshore-oil-field/312607.aspx, accessed 1 June 2011.

62 "South Korea's SK Energy, French Total find oil in Vietnam", MENAFN, 18 November 2009, available from http:/ / www.menafn.com/qn_news_story_s.asp?StoryId=1093283852, accessed 8 June 2011. 
provides easy business registration processes, efficient financial service, logistic hub and an advantageous tax regime, which has played significant roles in benefiting its neighboring countries. Vietnam and Indonesia both have huge market size, cheap labor and abundance of resources. Meanwhile, Malaysia and Thailand are still growing and have promising economic prospects. Overall, Korea benefits from the cheaper labor, natural resources, construction projects and larger market size of Southeast Asian countries. At the same time, Southeast Asian countries also benefit from the capital flows, advanced technology transfer, skill sets and financial expertise of Korea. With these mutual benefits, it is expected that economic cooperation and business exchange will continue to grow between Korea and Southeast Asian countries. 